\title{
KANDUNGAN AFLATOKSIN PADA LADA (Piper nigrum L.) INDONESIA DALAM PENGEMBANGAN STANDAR INTERNASIONAL CODEX
}

\section{The Contents of Aflatoxin in Indonesian Pepper to Codex Standard Development}

\author{
Suminto dan Reza Lukiawan \\ Pusat Penelitian dan Pengembangan Standardisasi, Badan Standardisasi Nasional \\ Gedung I BPPT Lantai 12, Jalan M.H. Thamrin No. 8, Jakarta, Indonesia \\ e-mail: lukiawan@bsn.go.id
}

Diterima: 13 April 2018, Direvisi: 23 Juli 2018, Disetujui: 27 Juli 2018

\begin{abstract}
Abstrak
Lada (Piper nigrum L.) merupakan salah satu rempah-rempah yang dihasilkan dari sektor perkebunan. Komoditas lada Indonesia juga diekspor ke negara lain. Adanya kandungan aflatoksin dalam rempah-rempah saat ini menjadi isu hangat dalam sidang Codex. Penelitian ini bertujuan untuk mengetahui kandungan aflatoksin pada lada dalam rangka mendukung pengembangan standar Codex. Sampel lada yang diambil yaitu biji lada yang berasal dari petani, pengepul dan eksportir. Lokus pengambilan sampel di Lampung, Bangka dan Kutai. Jumlah total sampel dalam penelitian ini sebanyak 26 sampel lada. Pengujian terhadap sampel lada yang telah diambil dilakukan di laboratorium yang telah bekerjasama yaitu Balai Pengujian Mutu Barang-Kementerian Perdagangan. Dalam analisis data kandungan aflatoksin pada lada, metode pengujian yang digunakan adalah metode AOAC Official Method 991.31.2005. Dari 26 sampel lada yang diuji diperoleh hasil dengan LOQ berturut-turut 1,07 ppb (Aflatoksin B1); 0,39 ppb (Aflatoksin B2); 1,35 ppb (Aflatoksin G1), dan 0,48 ppb (Aflatoksin G2). Hasil penelitian menunjukkan bahwa seluruh sampel lada nilai kandungan aflatoxin $B 1<L O Q$, sedangkan kandungan total aflatoxin juga $<L O Q$. Nilai kandungan tersebut masih dikategorikan aman untuk dikonsumsi karena dibawah ambang batas yang ditetapkan BPOM dan regulasi Uni Eropa.
\end{abstract}

Kata kunci: lada, aflatoksin, standar Codex.

\begin{abstract}
Pepper (Piper nigrum L.) is one that is produced from the plantation sector. Indonesian pepper commodity also dies to other countries. The presence of aflatoxin in spices is currently a hot issue in Codex time. This study is to determine the aflatoxin content in pepper in order to support the development of Codex standards. Pepper samples, which means seeds from farmers, collectors and exporters. Locus samples in Lampung, Bangka and Kutai. The total number of samples in this study were 26 pepper samples. Examination of samples carried out in a laboratory called the Goods Quality Testing Office of the Ministry of Trade. In analyzing the data on the aflatoxin content in pepper, the test method used was the Official Method of AOAC 991.31.2005. Of the 26 samples that produced results with LOQ-attended 1.07 ppb (Aflatoxin B1); 0,39 ppb (Aflatoxin B2); 1.35 ppb (Aflatoxin G1), and 0.48 ppb (Aflatoxin G2). The results showed that all samples were aflatoxin $B 1<L O Q$, while the total aflatoxin content was also $<L O Q$. This value is still categorized as safe to use because of under the limits set by BPOM and European Union regulations.
\end{abstract}

Keyword: pepper, aflatoxin, Codex standard.

\section{PENDAHULUAN}

Indonesia sebagai negara agraris mempunyai peluang yang cukup besar dalam mengembangkan ekspor produk pertanian, khususnya komoditas dari subsektor perkebunan. Lada (Piper nigrum L.) merupakan salah satu komoditi ekspor di subsektor perkebunan yang dapat memberikan kontribusi bagi devisa Indonesia selain kelapa sawit, karet, kopi dan teh (Soebtrianasari, 2008).
Kinerja ekspor komoditas lada Indonesia cukup signifikan dalam perdagangan lada dunia. Indonesia termasuk negara eksportir lada bagi permintaan pasar dunia. Hal ini terlihat pada Gambar 1 bahwa perkembangan volume ekspor lada di Indonesia selama periode tahun 20002014 cukup berfluktuasi namun terdapat kecenderungan menurun.

Negara kompetitor dalam perdagangan lada ialah Vietnam. Berdasarkan data dari Kementerian Pertanian (2015), pada periode tahun 2008-2012 rata-rata ekspor lada dari 
Vietnam sebesar 188.726 ton atau kontribusi pasarnya $33,42 \%$. Nilai tersebut menempatkan Vietnam pada posisi pertama. Indonesia berada di bawahnya dengan mampu mengekspor lada ratarata sebesar 181.607 ton dalam rentang periode yang sama. Lada dapat diandalkan sebagai komoditas unggulan ekspor, namun demikian budidaya lada nasional hampir seluruhnya dikelola oleh Perkebunan Rakyat yang masih belum menerapkan teknologi budidaya secara tepat, mutu hasil rendah karena panen dan pengolahan masih bersifat tradisional serta kebersihan/kesehatan produk belum terjamin (Kementerian Pertanian, 2007).

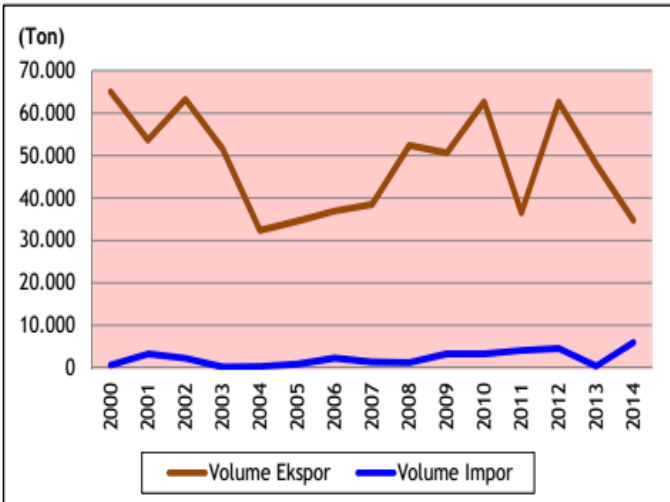

Gambar 1 Perkembangan volume ekspor dan volume impor lada Indonesia, 2000-2014.

Sumber: Kementerian Pertanian, 2015.

Selain itu, usaha tani lada rakyat masih memiliki banyak kekurangan, bahkan dalam beberapa tahun terakhir terjadi pengurangan areal lada yang disebabkan antara lain oleh: (a) kekeringan; (b) serangan hama dan penyakit, terutama penyakit busuk pangkal batang dan penyakit kuning; dan (c) konversi areal lada menjadi pertambangan atau lahan perkebunan lain, seperti kelapa sawit, karet atau kakao. (Kementerian Pertanian, 2013). Kepedulian terhadap keamanan pangan dari konsumen negara yang mengimpor lada semakin meningkat.

Menurut Putro (2001), masalah utama yang sering dikeluhkan oleh importir rempah Eropa terhadap produk lada Indonesia yaitu tingginya kadar kotoran dan kontaminasi mikroorganisme. Salah satu kontaminasi yang berpotensi timbul pada lada yaitu cemaran aflatoksin yang berasal dari jamur.

Aflatoksin diproduksi terutama oleh jamur Aspergillus flavus, A. parasiticus, $A$. nomius, $A$. pseudotamarii dan $A$. ochraceoroseus. Kontaminasi aflatoksin pada komoditi pertanian lebih sering terjadi di daerah beriklim tropis dan sub tropis karena suhu dan kelembabannya sesuai untuk pertumbuhan jamur (Handajani \&
Setyaningsih, 2006). Berdasarkan latar belakang tersebut dan dalam rangka penguatan posisi Indonesia di forum Codex terkait batas maksimum kandungan aflatoksin dalam lada, perlu diketahui nilai kandungan aflatoksin sehingga lada Indonesia mampu bersaing di pasar internasional.

Tujuan dari penelitian ini adalah untuk mengetahui kandungan aflatoksin pada lada Indonesia dalam rangka mendukung pengembangan standar Codex.

\section{TINJAUAN PUSTAKA}

\subsection{Definisi Lada}

Lada disebut juga merica atau sahang, yang mempunyai nama Latin Piper Albi Linn adalah sebuah tanaman yang kaya akan kandungan kimia, seperti minyak lada, minyak lemak, juga pati (Permadi, 2008). Lada bersifat sedikit pahit, pedas, hangat, dan antipiretik (Permadi, 2008). Tanaman ini sudah mulai ditemukan dan dikenal sejak puluhan abad yang lalu (Sarpian, 2003). Pada umumnya orang-orang hanya mengenal lada putih dan lada hitam yang sering dimanfaatkan sebagai bumbu dapur (Sarpian, 2003). Lada merupakan produk pertama yang diperdagangkan antara Barat dan Timur. Pada abad pertengahan tahun $1.100-1.500 \mathrm{M}$, perdagangan lada memiliki kedudukan yang sangat penting. Pada waktu itu lada digunakan sebagai alat tukar dan mas kawin, selain untuk keperluan rempah-rempah (Syakir, 2008).

\subsection{Karakteristik Tanaman Lada}

Lada (Piper nigrum Linn) termasuk dalam famili Piperaceae. Famili tersebut terdiri dari 10-12 genus dan 1.400 spesies, yang bentuknya beragam, seperti herba, semak, tanaman menjalar, hingga pohon-pohonan. Lada dari genus Piper merupakan spesies tanaman yang berasal dari Ghats, Malabar India (Rismunandar, 2007). Ciri morfologi dari tanaman lada antara lain:

1) Berakar tunggang (dikotil);

2) Perakarannya terdiri atas dua jenis, yaitu akar yang tumbuh dari buku di atas tanah (untuk menopang batang pokok dan menjalar atau memanjat pada tiang panjat atau inangnya) dan akar yang tumbuh dari buku di dalam tanah (sebagai penghisap makanan atau feeding roots);

3) Memiliki satu batang pokok dengan dua macam cabang (orthotropis atau vertikal dan plagiotropis atau horizontal), yang menyebabkan lada memiliki cabang yang banyak; 
4) Buku-buku batang agak membengkak, dimana dari buku-buku tersebut keluar daun, tunas, dan perbungaan;

5) Berdaun tunggal, letaknya berselang-seling pada cabang, berwarna hijau gelap, lembaran daun sebelah atas agak mengkilap dan sebelah bawahnya pucat dan berkelenjar;

6) Perbungaannya berbentuk bulir yang tumbuh di seberang daun, bunganya berukuran kecil, dan tanpa perhiasan bunga;

7) Buahnya buni tak bertangkai, berbiji satu, berkulit keras, dibalut oleh daging buah yang tebal; serta 8) memiliki tinggi antara 5-15 m.

\subsection{Aflatoksin}

Aflatoksin merupakan salah satu dari lima mikotoksin yang harus diwaspadai mengingat Aspergillus sp. sebagai produsennya banyak terdapat dan mencemari pangan dan produk pangan di Indonesia, serta racun yang dihasilkan bersifat karsinogenik, mutagenik, teratogenik, dan imunosupresif bagi manusia. Aflatoksin terutama aflatoksin B1 dapat menyebabkan hepatokarsinoma, hal ini dibuktikan berdasarkan analisis gen p53 (indikator gen termutasi pada penderita kanker) di mana telah terjadi mutasi sebesar $55 \%$ pada penderita hepatokarsinoma yang mengkonsumsi pangan tercemar AFB1 (Pitt dkk, 2000).

Hasil penelitian aflatoksin yang terus berkembang sejak ditemukannya empat dekade silam memperlihatkan bahwa produksi aflatoksin merupakan hasil interaksi antara genotipe/strain dan lingkungan tempat tumbuh Aspergillus sp. Saat ini dikenal enam jenis aflatoksin, yaitu $B 1$, B2, G1, G2, M1, dan M2. Aflatoksin M1 dan M2 merupakan metabolit aflatoksin B1 dan B2 yang terhidroksilasi dan dapat dijumpai dalam susu dan olahan susu yang diperoleh dari hewan yang mengonsumsi pakan yang tercemar aflatoksin.

Susu merupakan salah satu bahan pangan asal hewan yang potensial sebagai sumber masuknya aflatoksin ke dalam rantai makanan manusia melalui terbentuknya residu aflatoksin M1. Aflaltoksin M1 ini dapat terkonsumsi oleh manusia terutama bayi dan anak-anak melalui susu segar, susu pasteurisasi, susu UHT (Roussi dkk, 2002). Aflatoksin merupakan cemaran alami yang dihasilkan oleh beberapa spesies dari fungi Aspergillus yang banyak ditemukan di daerah beriklim panas dan lembap, terutama pada suhu $27-40^{\circ} \mathrm{C}\left(80-104^{\circ} \mathrm{F}\right)$ dan kelembaban relatif $85 \%$ (Robertson, 2005) Sebagai mikotoksin, senyawa tersebut lebih stabil dan tahan selama pengolahan makanan (Huang, 2007).
Spesies Aspergillus yang paling banyak ditemukan adalah Aspergillus flavus. Spesies ini memproduksi aflatoksin B, sedangkan A. parasiticus lebih banyak menghasilkan aflatoksin B dan G. Aflatoksin M1 dan M2 merupakan metabolit hasil hidroksilasi aflatoksin B1 dan B2 oleh sitokrom p450 1A2 pada manusia atau hewan yang mengonsumsi makanan yang tercemar aflatoksin. Aflatoksin M dijumpai dalam air susu dan urin (Gürbay, 2006).

\section{METODE PENELITIAN}

Penelitian ini menggunakan pendekatan deskriptif kuantitatif. Sudjana (2001) mendefinisikan penelitian deskriptif adalah penelitian yang berusaha mendeskripsikan suatu gejala, peristiwa, kejadian yang terjadi pada saat sekarang. Metode penelitian deskriptif dengan pendekatan secara kuantitatif digunakan apabila bertujuan untuk mendeskripsikan atau menjelaskan peristiwa atau suatu kejadian yang terjadi pada saat sekarang dalam bentuk angkaangka yang bermakna.

Data yang diperlukan dalam penelitian yaitu data primer dan sekunder. Data primer diperoleh dari hasil pengujian sampel lada, sedangkan data sekunder berupa data statistik perkebunan lada, SNI lada hitam dan lada putih. Pengambilan sampel lada tersebut dilakukan melalui suvei lapangan ke petani, pengepul, dan ekportir yang ada di daerah produksi lada. Adapun lokasi pengambilan sampel yaitu Lampung, Bangka dan Kutai. Pemilihan tiga daerah ini didasarkan pada jumlah produksi lada yang tergolong besar. Jumlah total sampel dalam penelitian ini sebanyak 26 sampel lada yang terdiri dari 7 sampel dari Lampung dengan rincian 3 (tiga) sampel dari petani, 3 (tiga) sampel dari pengepul dan 1 (satu) sampel dari eksportir), 9 sampel dari Bangka yang terdiri dari 3 (tiga) sampel dari petani, 3 (tiga) sampel dari pengepul dan 3 (tiga) sampel dari eksportir) dan 10 sampel dari Kutai yang terdiri dari 5 (lima) sampel dari petani dan 5 (lima) sampel dari pengepul.

Pengujian terhadap sampel lada yang telah diambil dilakukan di laboratorium yang telah bekerjasama yaitu Balai Pengujian Mutu BarangKementerian Perdagangan. Dalam analisis data kandungan aflatoksin pada lada, metode pengujian yang digunakan adalah metode AOAC Official Method 991.31.2005 dengan LOQ berturut-turut 1,07 ppb (Aflatoksin B1); 0,39 ppb (Aflatoksin B2); 1,35 ppb (Aflatoksin G1), dan 0,48 ppb (Aflatoksin G2). Limit deteksi (LOD) merupakan parameter uji batas terkecil yang dimiliki oleh suatu alat/instrumen. Limit Kuantisasi (LOQ) adalah konsentrasi atau jumlah terendah 
dari analit yang masih dapat ditentukan dan memenuhi kriteria akurasi dan presisi. Limit kuantisasi biasa disebut limit pelaporan (limit of reporting). Setelah diperoleh hasil pengujian kandungan aflatoksin sampel lada, kemudian dilakukan analisis data deskriptif kuantitatif (Kantasubrata, 2010).

\section{HASIL DAN PEMBAHASAN}

\subsection{Perkembangan Luas Areal Dan Produksi Lada Indonesia}

Tanaman lada Indonesia dilihat dari perkembangan luas areal mengalami tren yang meningkat. Gambar 2 menunjukkan bahwa pada tahun 1971 luas areal hanya 50.936 ha meningkat hingga seluas 168.080 ha pada tahun 2016. Sementara itu, luas areal paling tinggi dicapai pada tahun 2003, yaitu seluas 204.364 ha. Namun setelah tahun tersebut, kecenderungan luas areal tanaman lada menurun (semakin berkurang) dari tahun ke tahun. Hal ini disebabkan adanya konversi lahan tanaman lada yang diganti komoditi perkebunan lainnya.

Berdasarkan status pengusahaannya, perkebunan lada dibedakan menjadi perkebunan rakyat (PR) dan perkebunan besar swasta (PBS), sedangkan perkebunan besar negara (PBN) tidak mengusahakan lada. Dari kedua jenis pengusahaan tersebut, PR menguasai 99,87\% luas areal lada Indonesia dan sisanya sebesar $0,13 \%$ dimiliki oleh PBS. Oleh karena itu, kenaikan atau penurunan luas areal lada nasional sangat ditentukan oleh kenaikan atau penurunan luas areal lada PR. Perkebunan lada yang sebagian besar merupakan PR, masih dikelola secara tradisional oleh rakyat dengan pengetahuan teknologi budidaya yang masih rendah (Marlinda, 2008).

Luas areal berpengaruh terhadap hasil produksi dari lada tersebut. Jika ditinjau dari produksinya selama periode tahun 1971-2016 (Gambar 2) perkembangan berfluktuatif dengan tren yang cenderung meningkat. Pada tahun 1971, produksi lada hanya sebesar 26.661 ton, seiring dengan peningkatan produksi lada, pada tahun 2016 produksi sebesar 82.167 ton. Namun produksi terbesar terjadi pada tahun 2013 yaitu sebesar 91.039 ton.

Pada tahun 2013-2014 luas areal dan produksi mengalami masalah penurunan. Permasalahan terkait penurunan ini disebabkan oleh tidak bersemangatnya para petani dalam memelihara lada karena mereka merasa kurang puas dengan harga jual lada saat panen, ditambah lagi panen lada yang hanya setahun sekali. Karena hanya panen setahun sekali, para 98 petani lada banyak yang tidak memelihara tanaman lada dengan serius, bahkan beralih ke tanaman yang dapat dipanen lebih rutin seperti kakao dan karet. Para petani juga mengeluhkan stok pupuk yang minim.

Perkembangan Luas Areal dan Produksi Lada Indonesia

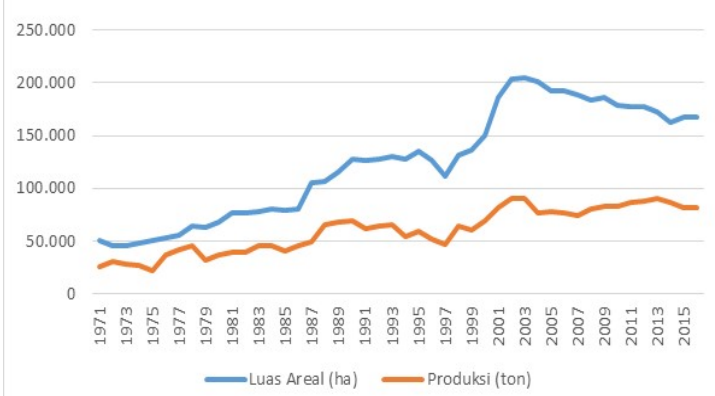

Gambar 2 Perkembangan luas areal dan produksi lada Indonesia.

Sumber: Ditjen Perkebunan, Kementerian Pertanian (2016).

\subsection{Perbandingan Standar Kandungan Aflatoksin Negara Lain}

Kandungan aflatoksin menjadi perhatian banyak negara yang tergabung dalam anggota Codex. Mengingat bahaya bagi kesehatan manusia dari aflatoksin yang dikonsumsi. Aflatoksin merupakan salah satu nama sekelompok senyawa yang termasuk mikotoksin dan paling toksik dibanding mikotoksin lainnya. Aflatoksin bersifat karsinogen dan banyak ditemukan pada produk pertanian. Aflatoksin dapat menyebabkan kanker dan ginjal pada manusia bila dikonsumsi secara berlebihan. Mengingat bahaya yang ditimbulkannya, maka WHO, FAO dan UNICEF telah menetapkan batas kandungan aflatoksin pada produk pertanian yang dikonsumsi, tidak lebih dari 30 ppb (Miskiyah \& Widaningrum, 2008).

Terdapat variasi penetapan standar batas maksimum kandungan aflatoksin yang berkisar antara 2-30 ppb untuk aflatoksin B1 dan 1-35 ppb untuk total aflatoksin. Beberapa negara menetapkan batas maksimum tersebut untuk semua jenis makanan. Namun ada juga negaranegara yang telah menetapkan secara spesifik untuk produk rempah-rempah (spices) antara lain Brazil, Bulgaria, Chile, Turki, Uruguay, negara Uni Eropa dan Indonesia (dalam bentuk rempahrempah bubuk).

Masyarakat Eropa yang sudah sejak lama menyukai rempah-rempah memberi perhatian khusus terhadap produk yang mereka impor. Hal ini dilakukan untuk melindungi masyarakat dari bahaya kandungan aflatoksin yang melebihi ambang batas. Oleh karena itu, Uni Eropa 
menetapkan standar yang cukup ketat untuk batas maksimum kandungan aflatoksin B1 dan total aflatoksin sebesar 5 ppb dan 10 ppb. Vietnam yang merupakan negara pesaing sebagai produsen lada menetapkan standar kandungan total aflatoksin sebesar 10 ppb untuk semua jenis makanan (All foods). Sedangkan India yang

Tabel 1 Persyaratan kandungan aflatoksin berbagai negara.

\begin{tabular}{|c|c|c|c|c|}
\hline No & Negara & Produk & $\begin{array}{c}\text { Aflatoxin B1 } \\
(\mu \mathrm{g} / \mathrm{Kg})\end{array}$ & $\begin{array}{c}\text { Aflatoxin Total } \\
(\mu \mathrm{g} / \mathrm{Kg})\end{array}$ \\
\hline 1) & Armenia & All foods & 5 & \\
\hline 2) & Barbados & All foods & & 20 \\
\hline 3) & Brazil & Spices & & 20 \\
\hline 4) & Bulgaria “** & Spices & 2 & 5 \\
\hline 5) & Chile & Spices & & 10 \\
\hline 6) & Colombia & All foods & & 10 \\
\hline 7) & Croatia & Spices & 30 & \\
\hline 8) & Cuba & All foods & & 5 \\
\hline 9) & Czech Republic “** & Spices & 20 & \\
\hline 10) & European Union & Spices* & 5 & 10 \\
\hline 11) & Finland"** & All Spices & & 10 \\
\hline 12) & Honduras & All foodstuffs & & 1 \\
\hline 13) & Hong Kong & All foodstuffs & 15 & 15 \\
\hline 14) & Iceland & Spices & 5 & 10 \\
\hline 15) & India & All Foods & & 30 \\
\hline 16) & Indonesia & Spices powder & 15 & 20 \\
\hline 17) & $\begin{array}{l}\text { Iran (Islamic } \\
\text { Republic of) }\end{array}$ & Spices & 5 & 10 \\
\hline 18) & Jamaica & $\begin{array}{l}\text { Foods and } \\
\text { Grains }\end{array}$ & & 20 \\
\hline 19) & Japan & All foods & 10 & \\
\hline 20) & Latvia"** & $\begin{array}{l}\text { Food products } \\
\text { of plant \& } \\
\text { animal origin }\end{array}$ & 5 & \\
\hline 21) & Liechtenstein & Spices & 5 & 10 \\
\hline 22) & Malaysia & All foods & & 35 \\
\hline 23) & Mauritius & All foods & 5 & 10 \\
\hline 24) & Morocco & All foods & 10 & \\
\hline 25) & Nigeria & All foods & 20 & \\
\hline 26) & Norway & Spices & 5 & 10 \\
\hline 27) & Oman & $\begin{array}{l}\text { Complete food } \\
\text { stuffs }\end{array}$ & 10 & \\
\hline 28) & Pakistan & Chilli & & 30 \\
\hline 29) & Salvador & All Foods & & 20 \\
\hline 30) & $\begin{array}{l}\text { Serbia and } \\
\text { Montenegro }\end{array}$ & Spices & 30 & \\
\hline 31) & Singapore & $\begin{array}{l}\text { All foods } \\
\text { except food for } \\
\text { infants or } \\
\text { young children }\end{array}$ & 5 & 5 \\
\hline
\end{tabular}

menjadi chair dalam pembahasan kandungan mikotoksin pada rempah-rempah di forum Codex menetapkan agak longgar untuk kandungan total aflatoksin sebesar $30 \mathrm{ppb}$ untuk semua jenis makanan. Nilai standar kandungan aflatoksin dari berbagai negara dapat dilihat pada Tabel 1. 


\begin{tabular}{|c|c|c|c|c|}
\hline No & Negara & Produk & $\begin{array}{c}\text { Aflatoxin B1 } \\
(\mu \mathrm{g} / \mathrm{Kg})\end{array}$ & $\begin{array}{c}\text { Aflatoxin Total } \\
(\mu \mathrm{g} / \mathrm{Kg})\end{array}$ \\
\hline & & $\begin{array}{l}\text { Food for infants } \\
\text { or } \\
\text { young children }\end{array}$ & 0.1 & NA \\
\hline 32) & South Africa & All food stuffs & 5 & 10 \\
\hline 33) & Sri Lanka & All foods & & 30 \\
\hline 34) & Switzerland & $\begin{array}{l}\text { Spices } \\
\text { excluding } \\
\text { Nutmeg } \\
\text { Nutmeg }\end{array}$ & 10 & 10 \\
\hline 35) & Thailand & All foods & & 20 \\
\hline 36) & Tunisia & All foods & 2 & \\
\hline 37) & Turkey & Spices & 5 & 10 \\
\hline 38) & USA & $\begin{array}{l}\text { All food except } \\
\text { milk }^{\star * *}\end{array}$ & & 20 \\
\hline 39) & Uruguay & $\begin{array}{l}\text { All foods and } \\
\text { spices }\end{array}$ & 5 & 20 \\
\hline 40) & Vietnam & All Foods & & 10 \\
\hline 41) & Zimbabwe & All Foods & 5 & \\
\hline \multicolumn{5}{|c|}{$\begin{array}{l}\text { Keterangan: } \\
\text { Spices*: Capsicum spp. (dried fruits thereof, whole or ground, including chillies, chilli } \\
\text { powder, cayenne and paprika); Piper spp. (fruits thereof, including white and black } \\
\text { pepper); Myristica fragrans (nutmeg); Zingiber officinale (ginger); Curcuma longa, based } \\
\text { on Commission Regulation (EC) No } 2174 / 2003 \text {. } \\
\text { a - Spices mentioned in footnote*, except from Capsicum spp. (Ref: Commission } \\
\quad \text { Regulation (EC) No } 2015 / 1137 \text { ) } \\
\text { b - Spices mentioned in footnote from dried fruits of Capsicum spp. (Ref: Commission } \\
\text { Regulation (EC) No 2015/1137) } \\
\text { **- Countries which comes under EU with MLs for mycotoxins } \\
\text { *** - The action level for aflatoxin M1 in milk in the U.S. is } 0.5 \mu \mathrm{g} / \mathrm{kg}\end{array}$} \\
\hline
\end{tabular}

Indonesia memiliki regulasi untuk mengatur batas cemaran mikroba dan kimia dalam makanan yaitu merujuk pada Peraturan Kepala BPOM Nomor HK.00.06.1.52.4011. Dalam regulasi ini salah satu yang diatur adalah terkait kandungan aflatoksin pada rempah-rempah bubuk. Batas maksimum kandungan afaltoksin B1 sebesar 15 ppb dan total afaltoksin sebesar 20 ppb.

\subsection{Hasil Pengujian Kandungan Aflatoksin Sampel Lada}

\subsubsection{Hasil Pengujian Sampel Lada Lampung}

Sebagian besar penduduk di Provinsi Lampung bergantung pada sektor perkebunan seperti kopi, cengkeh dan lada. Lada merupakan tanaman rempah yang cukup banyak dibudidayakan oleh petani di Lampung. Umumnya budidaya lada di Lampung dilakukan dengan sistem tiang panjat hidup. Bahan tanam yang digunakan yakni sulur panjat yang memiliki cukup akar lekat sehingga dapat merambat ke tiang panjat. Lada akan berbuah pada umur 3 tahun. Untuk mempercepat berproduksinya, lada dapat dibudidayakan dengan sistem tanpa tiang panjat atau lebih dikenal dengan lada perdu yang dapat berproduksi pada umur 1 tahun (mengikuti musim berbuah lada). Jenis lada yang dihasilkan umumnya lada hitam (black pepper).

Ada beberapa daerah di Provinsi Lampung yang merupakan penghasil lada. Berdasarkan data dari Ditjen Perkebunan Tahun 2015 hanya 3 (tiga) dari 14 kabupaten yang tidak menghasilkan lada yaitu kabupaten Tulang Bawang, kabupaten Tulang Bawang Barat dan kabupaten Mesuji. Data secara keseluruhan dari daerah kabupaten yang menghasilkan lada tersaji pada Tabel 2.

Penelitian ini mengambil sampel di daerah Lampung Utara, Lampung Barat dan Bandar Lampung Provinsi Lampung. Sampel lada yang terkumpul sebanyak 7 sampel. Berdasarkan hasil pengujian laboratorium, seluruh sampel yang diambil nilai kandungan aflatoksin B1 dan total aflatoksin dikategorikan aman. Nilainya 
$\begin{array}{llllllll}\text { masih di bawah persyaratan kandungan aflatoksin } & 15 & \mathrm{ppb} & \text { (aflatoksin } & \mathrm{B} 1) & \text { dan } & 20 & \mathrm{ppb}\end{array}$ (total pada spices yang ditetapkan BPOM yaitu sebesar aflatoksin).

Tabel 2 Luas areal dan produksi lada dari 14 kabupaten di Provinsi Lampung Tahun 2015.

\begin{tabular}{clcc}
\hline No. & Kabupaten & Luas Areal (ha) & Produksi (ton) \\
\hline 1 & Lampung Selatan & 84 & 43 \\
2 & Pesawaran & 340 & 83 \\
3 & Lampung Tengah & 117 & 96 \\
4 & Lampung Utara & 11.401 & 3.689 \\
5 & Lampung Barat & 7.686 & 3.644 \\
6 & Tanggamus & 7.371 & 2.154 \\
7 & Tulang Bawang & - & - \\
8 & Lampung Timur & 4.815 & 1.958 \\
9 & Way Kanan & 10.088 & 1.317 \\
10 & Bandar Lampung & 12 & 8 \\
11 & Pringsewu & 354 & 113 \\
12 & Tulang Bawang Barat & - & - \\
13 & Mesuji & - & 1.755 \\
14 & Pesisir Barat & 3.595 & - \\
\hline
\end{tabular}

Sumber: Ditjenbun, Kementerian Pertanian (2016).

Apabila mengacu pada batas maksimum standar Uni Eropa yang menetapkan kandungan aflatoksin B1 sebesar $5 \mathrm{ppb}$ dan total aflatoksin sebesar $10 \mathrm{ppb}$, maka seluruh sampel lada tidak ada yang melebihi ambang batas. Nilai hasil pengujian kandungan aflatoksin sampel lada yang berasal dari Provinsi Lampung secara lengkap dapat dilihat pada Tabel 3.

Tabel 3 Hasil pengujian kandungan aflatoksin lada dari Lampung.

\begin{tabular}{lllccc}
\hline No. & Sampel & Rantai & Satuan & $\begin{array}{c}\text { Aflatoxin B1 } \\
\text { LOQ: 1,07 }\end{array}$ & $\begin{array}{c}\text { Total Aflatoxin } \\
\text { LOQ: 3,29 }\end{array}$ \\
\hline 1 & Sampel 1 & 001-PETANI & $\mathrm{ppb}$ & $<$ & $<$ \\
2 & Sampel 2 & 002-PETANI & $\mathrm{ppb}$ & $<$ & $<$ \\
3 & Sampel 3 & 003-PETANI & $\mathrm{ppb}$ & $<$ & $<$ \\
4 & Sampel 4 & 001-PENGEPUL & $\mathrm{ppb}$ & $<$ & $<$ \\
5 & Sampel 5 & 002-PENGEPUL & $\mathrm{ppb}$ & $<$ & $<$ \\
6 & Sampel 6 & 003-PENGEPUL & $\mathrm{ppb}$ & $<$ & $<$ \\
7 & Sampel 7 & 001-EKSPORTIR & $\mathrm{ppb}$ & $<$ & $<$ \\
\hline
\end{tabular}

Sumber: Data Hasil Uji Sampel, 2017.

\subsection{2 \\ Hasil Pengujian Sampel Lada Bangka Belitung}

Provinsi Bangka Belitung dikenal sebagai daerah penghasil lada putih yang terkenal dengan brand Muntok White Pepper. Namun sebenarnya perkebunan lada tidak hanya ditemukan di Muntok. Lada atau merica disebut oleh orang
Bangka Belitung dengan Sahang. Tanaman lada hanya berumur sekitar 6 atau 7 tahun saja. Tanaman ini berdaun tunggal dengan batang yang berbuku-buku dan tumbuh merambat.

Berbeda dengan daerah lain, Bangka menghasilkan jenis lada putih. Yang membedakan lada putih dan lada hitam adalah proses pasca panen. Lada hitam biasanya dipetik 
sebelum buahnya benar-benar matang yang kemudian dikeringkan. Sementara itu, lada putih diperoleh dari lada yang dipetik ketika sudah matang dan melalui proses pencucian dan perendaman untuk melepaskan tangkai dan mengupas kulit luar sebelum dijemur dibawah panas matahari.

Biasanya lada direndam di sungai-sungai yang airnya bersih dan mengalir untuk menjaga mutu. Di perkampungan lada, apabila sedang musim panen, biasanya halaman rumah-rumah petani akan dipenuhi tikar-tikar yang diatasnya diletakkan butiran lada yang telah selesai direndam. Saat itu, perkampungan tersebut akan dipenuhi aroma khas lada yang sangat menyengat sisa proses perendaman. Tentu saja bau menyengat itu tidak seberapa dibandingkan bau lada yang sedang direndam. Lada putih akan siap dijual atau digunakan setelah proses penjemuran selesai. Untuk mengetahui pakah lada telah kering dengan baik dapat diketahui dengan cara menggigitnya saja. Jika digigit biji lada kering terbelah dua atau lebih, maka lada itu telah telah kering dan siap dijual atau digunakan.

Tabel 4 Luas areal dan produksi lada dari 7 kabupaten di Provinsi Bangka Belitung Tahun 2015.

\begin{tabular}{llrr}
\hline No. & Kabupaten & Luas Areal (ha) & Produksi (ton) \\
\hline 1 & Bangka & 4.715 & 3.359 \\
2 & Bangka Tengah & 2.963 & 1.900 \\
3 & Bangka Selatan & 23.368 & 15.711 \\
4 & Bangka Barat & 5.404 & 4.413 \\
5 & Belitung & 7.976 & 4.213 \\
6 & Belitung Timur & 3.584 & 1.812 \\
7 & Kota Pangkal Pinang & - & -
\end{tabular}

Sumber: Ditjenbun, Kementerian Pertanian (2016)

Ada beberapa daerah di Provinsi Bangka Belitung yang merupakan penghasil lada. Berdasarkan data dari Ditjen Perkebunan Tahun 2015 hanya 1 (satu) dari 7 kabupaten yang tidak menghasilkan lada yaitu kota Pangkal Pinang. Data secara keseluruhan dari daerah kabupaten yang menghasilkan lada tersaji pada Tabel 4.

Penelitian ini juga mengambil sampel di daerah Bangka Provinsi Babel. Sampel lada yang terkumpul sebanyak 9 sampel. Berdasarkan hasil pengujian laboratorium, seluruh sampel yang diambil nilai kandungan aflatoksin B1 dan total

aflatoksin dikategorikan aman. Nilainya masih dibawah persyaratan kandungan aflatoksin pada spices yang ditetapkan BPOM yaitu sebesar 15 ppb (aflatoksin B1) dan 20 ppb (total aflatoksin). Apabila mengacu pada batas maksimum standar Uni Eropa yang menetapkan kandungan aflatoksin B1 sebesar 5 ppb dan total aflatoksin sebesar 10 ppb, maka seluruh sampel lada tidak ada yang melebihi ambang batas. Nilai hasil pengujian kandungan aflatoksin sampel lada yang berasal dari Provinsi Babel secara lengkap dapat dilihat pada Tabel 5.

Tabel 5 Hasil pengujian kandungan aflatoksin lada dari Babel.

\begin{tabular}{cllccc} 
No. & Sampel & \multicolumn{1}{c}{ Rantai } & Satuan & $\begin{array}{c}\text { Aflatoxin B1 } \\
\text { LOQ: 1,07 }\end{array}$ & $\begin{array}{c}\text { Total Aflatoxin } \\
\text { LOQ: 3,29 }\end{array}$ \\
\hline 1 & Sampel 1 & 001-PETANI & ppb & $<$ & $<$ \\
2 & Sampel 2 & 002-PETANI & ppb & $<$ & $<$ \\
3 & Sampel 3 & 003-PETANI & ppb & $<$ & $<$ \\
4 & Sampel 4 & 001-PENGEPUL & ppb & $<$ & $<$ \\
5 & Sampel 5 & 002-PENGEPUL & ppb & $<$ & $<$ \\
6 & Sampel 6 & 003-PENGEPUL & ppb & $<$ & $<$ \\
7 & Sampel 7 & 001-EKSPORTIR & ppb & $<$ & $<$ \\
8 & Sampel 8 & 002-EKSPORTIR & ppb & $<$ & $<$ \\
9 & Sampel 9 & 003-EKSPORTIR & ppb & $<$ & $<$ \\
\hline
\end{tabular}

Sumber: Data Hasil Uji Sampel (2017). 


\subsubsection{Hasil Pengujian Sampel Lada Kutai Kartanegara}

Ada beberapa daerah di Provinsi Kalimantan Timur yang merupakan penghasil lada.
Berdasarkan data dari Ditjen Perkebunan Tahun 2015 sebanyak 6 (enam) dari 14 kabupaten/kota yang tidak menghasilkan lada. Data secara keseluruhan dari daerah kabupaten/kota yang menghasilkan lada tersaji pada Tabel 6.

Tabel 6 Luas areal dan produksi lada dari 14 kabupaten/kota di Provinsi Kalimantan Timur Tahun 2015.

\begin{tabular}{clcc}
\hline No. & Kabupaten & Luas Areal (ha) & Produksi (ton) \\
\hline 1 & Paser & 98 & 30 \\
2 & Kutai Kartanegara & 5.428 & 4.763 \\
3 & Kutai Barat & 48 & 1 \\
4 & Kutai Timur & 422 & 80 \\
5 & Berau & 2.018 & 839 \\
6 & Bulungan & - & - \\
7 & Malinau & - & - \\
8 & Nunukan & - & - \\
9 & Penajam & 1.455 & 1.196 \\
10 & Tana Tidung & - & - \\
11 & Kota Tarakan & - & - \\
12 & Kota Bontang & - & - \\
13 & Kota Balikpapan & 60 & 3 \\
14 & Kota Samarinda & 77 & 11 \\
\hline
\end{tabular}

Sumber: Ditjenbun, Kementerian Pertanian (2016).

Lokus ketiga dari penelitian ini mengambil sampel di daerah Kutai Kartanegara Provinsi Kalimantan Timur. Sampel lada yang terkumpul sebanyak 10 sampel. Berdasarkan hasil pengujian laboratorium, seluruh sampel yang diambil nilai kandungan aflatoksin B1 dan total aflatoksin dikategorikan aman. Nilainya masih dibawah persyaratan kandungan aflatoksin pada spices yang ditetapkan BPOM yaitu sebesar 15 ppb (aflatoksin B1) dan 20 ppb (total aflatoksin). Apabila mengacu pada batas maksimum standar Uni Eropa yang menetapkan kandungan aflatoksin B1 sebesar $5 \mathrm{ppb}$ dan total aflatoksin sebesar $10 \mathrm{ppb}$, maka seluruh sampel lada tidak ada yang melebihi ambang batas. Nilai hasil pengujian kandungan aflatoksin sampel lada yang berasal dari Provinsi Kutai secara lengkap dapat dilihat pada Tabel 7.

Tabel 7 Hasil pengujian kandungan aflatoksin lada dari Kutai Kartanegara.

\begin{tabular}{lllccc}
\hline No. & Sampel & Rantai & Satuan & $\begin{array}{l}\text { Aflatoxin B1 } \\
\text { LOQ: 1,07 }\end{array}$ & $\begin{array}{l}\text { Total Aflatoxin } \\
\text { LOQ: 3,29 }\end{array}$ \\
\hline 1 & Sampel 1 & 001-PETANI & ppb & $<$ & $<$ \\
2 & Sampel 2 & 002-PETANI & ppb & $<$ & $<$ \\
3 & Sampel 3 & 003-PETANI & ppb & $<$ & $<$ \\
4 & Sampel 4 & 004-PETANI & ppb & $<$ & $<$ \\
5 & Sampel 5 & 005-PETANI & ppb & $<$ & $<$ \\
6 & Sampel 6 & 001-PENGEPUL & ppb & $<$ & $<$ \\
7 & Sampel 7 & 002-PENGEPUL & ppb & $<$ & $<$ \\
8 & Sampel 8 & 003-PENGEPUL & ppb & $<$ & $<$ \\
9 & Sampel 9 & 004-PENGEPUL & ppb & $<$ & $<$ \\
10 & Sampel 10 & 005-PENGEPUL & ppb & $<$ & $<$ \\
\hline
\end{tabular}

Sumber: Data Hasil Uji Sampel (2017). 


\section{KESIMPULAN}

Berdasarkan hasil pengujian terhadap 26 sampel lada yang berasal dari petani, pengepul dan eksportir di 3 (tiga) lokus penelitian yaitu Lampung, Bangka Belitung dan Kutai Kartanegara diketahui bahwa keseluruhan sampel nilai kandungan aflatoksin B1 <LOQ $(1,07 \mathrm{ppb})$ dan total aflatoksin < LOQ (3,29 ppb). Hal ini dapat memenuhi persyaratan regulasi kandungan aflatoksin pada spices yang ditetapkan BPOM yaitu sebesar 15 ppb (aflatoksin B1) dan 20 ppb (total aflatoksin) serta juga memenuhi batas maksimum standar Uni Eropa yang menetapkan kandungan aflatoksin $\mathrm{B} 1$ sebesar 5 ppb dan total aflatoksin sebesar $10 \mathrm{ppb}$.

Penelitian ini dapat menjadi pertimbangan untuk penurunan batas maksimum level kandungan Aflatoksin B1 dari nilai 15 ppb dan Total Aflatoksin dari nilai 20 ppb dalam rangka posisi Indonesia dalam pengembangan standar internasional Codex. Penelitian lanjutan perlu dilakukan terkait ketertelusuran daerah asal produk rempah-rempah yang mengalami penolakan ekspor khususnya dari negara Eropa untuk mengetahui akar penyebab dari ketidaksesuaian standar. Pembinaan pengelolaan pascapanen kepada para pelaku usaha lada terus dilakukan guna menjaga standar mutu lada serta rendahnya kandungan aflatoksin yang dapat muncul.

\section{UCAPAN TERIMA KASIH}

Ucapan terima kasih kami sampaikan kepada Pusat Penelitian dan Pengembangan Standardisasi BSN yang telah membiayai penelitian ini pada Tahun 2017. Ucapan terima kasih juga kami sampaikan kepada pihak-pihak yang mendukung penelitian ini.

\section{DAFTAR PUSTAKA}

FAO. (2004). Worlwide regulations for mycotoxins in food and feed in 2003. Retrieved from http://www.fao.org/docrep/007/y5499e/y5 499e00.htm diakses tanggal 12 April 2018-04-13.

Gürbay A, Aydın S, Girgin G, Engin AB, Şahin G. (2006). Assessment of Aflatoxin M1 Levels in Milk in Ankara, Turkey. Food Control 2006; 17 (1): 1-4.

Handajani, N.S, \& R. Setyaningsih. (2006). Identifikasi Jamur dan Deteksi Aflatoksin B1 terhadap Petis Udang Komersial. Biodiversitas 7 (3): $212-215$.
Huang, J. Elmashni, D. (2007). Analysis of Aflatoxins Using Fluorescence Detection. Thermo Scientific Application Note 381 2007.

Kantasubrata, Y. (2010). "Validasi Metode" Diktat Validasi Metode, Pusat Penelitian KimiaLIPI. Bandung.Kementerian Pertanian. (2007). Pedoman Teknis Budidaya Lada (Good AgriculturalPractices/GAP). Direktorat Jenderal Perkebunan DepartemenPertanian. Jakarta.

Kementerian Pertanian. (2013). Pedoman Teknis Pengembangan Tanaman Lada Tahun 2014. Direktorat Jenderal Perkebunan Kementerian Pertanian. Jakarta.

Kementerian Pertanian. (2015). Outlook Lada : Komoditas Pertanian Subsektor Perkebunan. Pusat Data dan Sistem Informasi Pertanian, Sekretariat Jenderal, Kementerian Pertanian. Jakarta.

Kementerian Pertanian. (2016). Statistik Perkebunan Indonesia Komoditas Lada 2015-2017. Direktorat Jenderal Perkebunan Kementerian Pertanian. Jakarta.

Marlinda, B. (2008). Analisis Daya Saing Lada Indonesia di Pasar Internasional. Bogor: Program Studi Ekonomi Pertanian dan Sumberdaya Fakultas Pertanian Institut Pertanian Bogor.

Miskiyah dan Widaningrum. (2008). Pengendalian Aflatoksin pada Pascapanen Jagung Melalui Penerapan HACCP. Jurnal Standardisasi 10 (1): 1-10.

Permadi, A. (2008). Membuat Kebun Tanaman Obat. Retrieved from https://www.google.com/books?hl=en\&lr=\& id=YVRjJfRD3f8C\&oi=fnd\&pg=PA32\&dq= Membuat+Kebun+tanaman+Obat\&ots $=x P$ 4kYjrfOF\&sig=uTSnl8cLYMGcD5NW2r3c3 Cl8dM4.Pitt JI, Basilico JC, Abarca ML, Lopez C. (2000). Mycotoxin and toxigenic fungi. Medical Mycology. 38 (Suppl 1) : 4146.

Putro, S. (2001). Peluang pasar rempah Indonesia di Eropa. Prosiding Simposium Rempah Indonesia. Kerjasama Masyarakat Rempah Indonesia (MaRI) dengan Puslitbangbun, Jakarta, 13 - 14 September 2001. HIm 25 32.

Rismunandar. (2007). Lada Budidaya dan Tataniaganya. Jakarta: Penebar Swadaya.

Robertson. (2005). IC494 2005;23:185-186.

Roussi,V., A. Govaris, A. Varagouli And N.A.Botsoglou. (2002). Occurrence of 
aflatoxin $\mathrm{M}(1)$ in raw and market milk commercialized in Greece. Food Addit Contam. 19(9): 863 - 868.

Sarpian, T. (2003). Pedoman Berkebun Lada Dan Analis Usaha Tani. Retrieved from https://www.google.com/books?hl=en\&lr=\& id=p_6ugzfjg8C\&oi=fnd\&pg=PA7\&dq=Ped oman+Berkebun+Lada+dan+Analisis+Usa ha+Tani\&ots=P3_BEtUzTg\&sig=gYQuYC HKVohCjOrSK6C-Kwyqw50.

Soebtrianasari, D. (2008). Analisis Penawaran dan Permintaan Lada Putih Indonesia di
Pasar Internasional. Skripsi. Program Studi Manajemen Agribisnis. Fakultas Pertanian. Institut Pertanian Bogor. Bogor.

Sudjana, Nana dan Ibrahim. (2001). Penelitian dan Penilaian Pendidikan. Bandung : Sinar Baru Algensindo.

Syakir, M. (2008). Ragam teknologi budidaya lada. Teknologi Tanaman Rempah dan Obat. Retrieved from http://balittro.litbang.pertanian.go.id/ind/ima ges/file/Perkembangan TRO/20no1/2Syakir.pdf. 
